\title{
The Effects of Polystyrene Species and Fiber Direction on Thermal Conductivity of Plywood
}

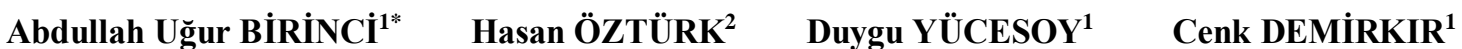 \\ ${ }^{1 *}$ Karadeniz Technical University, Faculty of Forestry, Department of Forest Engineering, Kanuni Campus, Trabzon, Turkey \\ ${ }^{2}$ Karadeniz Technical University, Arsin Vocational School, Materials and Material Processing Technologies, Trabzon, Turkey
}

How to cite: Birinci, A.U., Öztürk, H., Yücesoy, D. \& Demirkır, C. (2020). The effects of polystyrene species and fiber direction on thermal conductivity of plywood. J. Anatolian Env. and Anim. Sciences, 5(5), 825-828.

Atıf yapmak için: Birinci, A.U., Öztürk, H., Yücesoy, D. \& Demirkır, C. (2020). Polistiren türü ve lif yönünün kontrplakların isıl iletkenliği üzerine etkisi. Anadolu Çev. ve Hay. Dergisi, 5(5), 825-828.

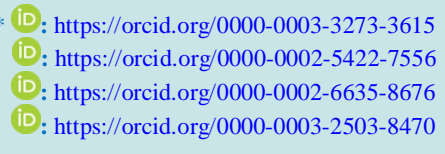

*Corresponding author's: Abdullah Uğur Birinci

Karadeniz Technical University, Department

of Forest Industry Engineering, Kanuni

Campus, Trabzon, Turkey.

冈: ugurbirinci@ktu.edu.tr

Mobile telephone: +90 (534) 2508387

Telephone $\quad:+90(462) 3771560$

Fax $\quad:+90(462) 3257499$
Abstract: Thermal conductivity of wood material is superior to other building materials because of its porous structure. Thermal conductivity is used to estimate the ability of insulation of material. Thermal conductivity of wood material has varied according to wood species, direction of wood fiber, specific gravity, moisture content, resin type, and addictive members used in manufacture of wood composite panels. The aim of study was to determine the effect of polystyrene species and fiber direction on thermal conductivity of plywood panels. In the study, two different wood types (black pine and spruce), two different fiber directions (parallel and perpendicular to the plywood fiber direction), two different types of insulator (expanded polystyrene-EPS and extruded polystyrene-XPS) and phenol formaldehyde glue were used as the adhesive type. Thermal conductivity of panels was determined according to ASTM C 518 \& ISO 8301. As a result of the study, the lowest thermal conductivity values were obtained in the perpendicular fiber direction of the spruce plywood using XPS as insulation material. The use of XPS as an insulation material in plywood has given lower thermal conductivity values than EPS.

Keywords: Thermal conductivity, Polystyrene, Fiber direction, Black pine, Spruce.

\section{Polistiren Türü ve Lif Yönünün Kontrplakların Isıl İletkenliği Üzerine Etkisi}

*Sorumlu yazarın:

Abdullah Ugur BİRINCİ

Karadeniz Teknik Üniversitesi Orman

Fakültesi Orman Endüstri Mühendisliği

Bölümü, Kanuni Kampusü Trabzon, Türkiye

$\triangle$ : ugurbirinci@ktu.edu.tr

Cep telefonu : $+90(534) 2508387$

Telefon : $+90(462) 3771560$

Faks : : +90(462) 3257499
Öz: Ahşap malzemenin 1S1 iletkenliği gözenekli yapısı nedeniyle diğer yapı malzemelerinden üstündür. Isı iletkenliği, malzemenin yalıtım kabiliyetini tahmin etmek için kullanılır. Ahşap malzemenin 1sıl iletkenliği, ağaç türü, ağaç lifinin yönü, özgül ağırlığı, nem içeriği, reçine türü ve ahşap kompozit panellerin imalatında kullanılan katkı maddelerine göre değişmektedir. $\mathrm{Bu}$ çalışmanın amacı, polistiren türlerinin ve lif yönünün kontrplak panellerin ssıl iletkenliği üzerindeki etkisini belirlemektir. Çalışmada, iki farklı ağaç türü (karaçam ve ladin), iki farklı lif yönü (kontrplak lif yönüne paralel ve dik), iki farklı tipte yalıtkan (genleştirilmiş polistiren-EPS ve ekstrüde polistiren-XPS) ve tutkal türü olarak fenol formaldehit tutkalı kullanılmıştır. Panellerin 1sıl iletkenliği ASTM C 518 ve ISO 8301'e göre belirlenmiştir. Çalışma sonucunda, en düşük ısıl iletkenlik değerleri liflere dik yöndeki ladin kontrplaklarda izolasyon malzemesi olarak XPS kullanılması durumunda elde edilmiştir. Kontrplaklarda izolasyon malzemesi olarak XPS kullanılması durumunda EPS ye göre daha düşük ısıl iletkenlik değerleri elde edilmiştir.

$\underline{\text { Anahtar kelimeler: Isıl iletkenlik, Polistiren, Lif yönü, Karaçam, Doğu Ladin. }}$ 


\section{INTRODUCTION}

In order to prevent the rapid depletion of energy resources in the world, all countries, especially developed countries, have developed methods of controlling their energy needs and using energy effectively. Efficient use of energy can be achieved with thermal insulation. In particular, it contains the building elements that separate the interior environment of the building from the external environment (Uysal et al., 2011). Due to the porous nature of wooden materials, their thermal conductivity is very good compared to other building materials. Thermal Conductivity is an important parameter in determining the heat transfer rate (Ozdemir et al., 2013; Gu and ZinkSharp, 2005). Thermal conductivity is used to determine the insulating ability of materials. The thermal conductivity of wood varies according to the wood type, fiber direction, glue type and additives used in the production of wood composite materials (Demirkır, 2014).

Reducing energy consumption of buildings is required in order to counteract global warming induced by carbon dioxide, and thermal insulation of a building is an important part of this process. One of the development concepts used in the design of insulation materials is to aim to achieve a low thermal conductivity (k-value). An alternative development concept is to aim to use environmentally friendly products. One aspect of being environmentally friendly is effective utilization of unused resources. Using agricultural wastes, forest product wastes, textile wastes, and so on, as the raw materials of thermal insulation products is favorable for working towards a sustainable society based on resource recycling (Sekino, 2016). Many types of insulation materials are available which differ with regard to thermal properties and many other material properties as well as cost. Current thermal insulation materials in the construction market are generally inorganic materials e.g. extruded polystyrene (XPS), expanded polystyrene (EPS), polyisocyanurate and polyurethane foam (Cetiner and Shea, 2018). Expanded polystyrene is proved to be an excellent insulating medium which exhibits consistent thermal performance over the range of temperatures normally encountered in buildings (Lakatos and Kalmar, 2012). Expanded polystyrene has a thermal conductivity coefficient $\lambda=0.03 \mathrm{w} / \mathrm{mK}$, which has led to the wide use of polystyrene panels for the rehabilitation and thermal insulation of buildings (Claudiu et al., 2015). Expanded polystyrene, commonly known as styrofoam, is a polymer material present in a wide variety of products used in daily life, ranging from disposable goods to construction materials, due to its low cost, durability, and light weight (Jang et al., 2018). Its manufacture involves the heating of expandable beads of polystyrene with steam, and the placement of these heated expanded polystyrene beads into moulds to create prismatic blocks of EPS (Horvath, 1994). EPS has a very low density. An individual bead of EPS would be approximately spher-ical and contains only about $2 \%$ of polystyrene and about $98 \%$ of air (Dissanayake et al., 2017). The EPS is a chemically inert material not biodegradable, ie, it does not decompose, does not disintegrate, does not disappear in the environment and does not contain CFCs, consequently the EPS does not chemically contaminate the soil, water or air. However it can be an environmental problem if not recycled because it is considered an eternal material and it takes up too much space (due to its low density) (Schmidt et al., 2011.). Hence, reuse of EPS is beneficial in terms of environmental protection (Fernando et al., 2017). Wood-styrofoam composite (WSC) panels may be a very suitable solution for environmental pollution caused by styrofoam waste and also formaldehyde released from wood based panels (Demirkir et al., 2013).

The aim of study was to determine the effect of polystyrene species and fiber direction on thermal conductivity of plywood panels.

\section{MATERIALS AND METHOD}

Wood Material and Manufacturing of Plywood: Black pine (Pinus nigra) and spruce (Picea orientalis L.) were used in this study. The logs were steamed for 12-16 hours before veneer production. A rotary type peeler (Valette\& Garreau - Vichy, France) with a maximum horizontal holding capacity of $800 \mathrm{~mm}$ was used for veneer manufacturing and rotary cut veneer sheets with dimensions of $1.2 \times 2.4 \mathrm{~m}$ by $2 \mathrm{~mm}$ were clipped. Vertical opening was $0.5 \mathrm{~mm}$ and horizontal opening was $85 \%$ of the veneer thickness in veneer manufacturing process. After rotary peeling, the veneer sheets were oven-dried at $110^{\circ} \mathrm{C}$, for $5-7 \%$ moisture content in a laboratory scale jet veneer dryer (manufactured by Hildebrand Holztechnik $\mathrm{GmbH})$.

Seven-ply plywood panels, $14 \mathrm{~mm}$ thick, were manufactured by using phenol formaldehyde (PF) glue resin with $47 \%$ solid content. Veneer sheets were conditioned to approximately 6-7\% moisture content in a conditioning chamber before gluing. The glue was applied at a rate of $160 \mathrm{~g} / \mathrm{m}^{2}$ to the single surface of veneer by using a four-roller spreader. The assembled samples were pressed in a hot press at a pressure of $8 \mathrm{~kg} / \mathrm{cm}^{2}$ and at $140^{\circ} \mathrm{C}$ for $14 \mathrm{~min}$. Two replicate plywood panels were manufactured from each group.

Method: The thermal conductivity of the panels were determined according to ASTM C 518 \& ISO 8301 (2004). Sample size required is 300 x $300 \times 14 \mathrm{~mm}$. Two specimens were used for each test group. The Lasercomp 
Fox-314 Heat Flow Meter shown in Fig. 1 was used for the determination of thermal conductivity. The top and lower layers of it was set for $20^{\circ} \mathrm{C}$ and $40^{\circ} \mathrm{C}$ for all specimens, respectively. The panels temperature during the measurement of the thermal conductivity was maintained to these constant temperatures.

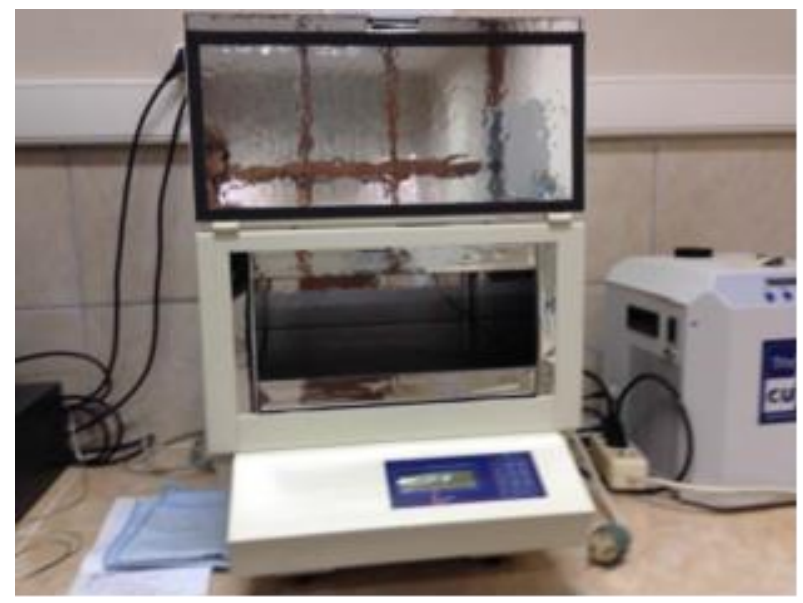

Figure 1. Lasercomp Fox-314 heat flow meter.

\section{RESULTS AND DISCUSSION}

The thermal conductivity coefficient values of the plywood-insulation material combinations used within the scope of the study are given in Figure 2 according to the type of wood, fiber direction and insulation materials.

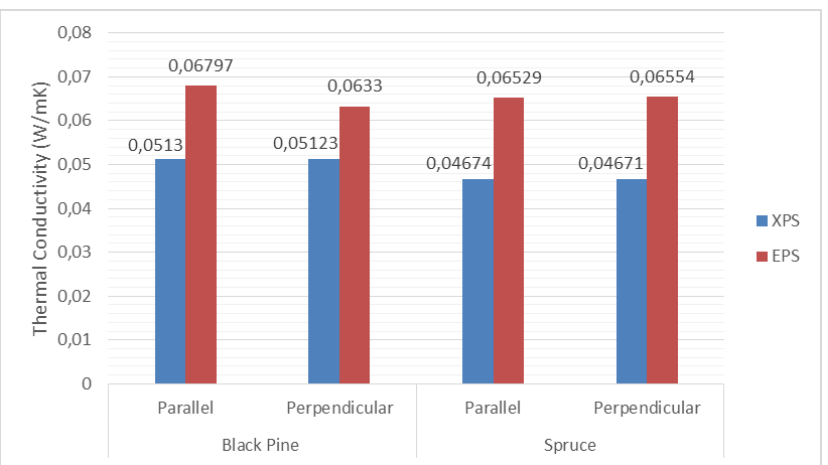

Figure 2. Thermal conductivity coefficients according to combination groups.

When Figure 2 is examined, it is seen that the insulating material type and the wood type and fiber direction of the plywood change the thermal conductivity of the groups formed. When the tree type is examined, it has been determined spruce plywood shows a better insulation feature than the larch. As the reason why larch gives higher thermal conductivity values, it can be shown that its density is higher than spruce plywood. In a study, pine species with different specific weights were examined and it was found that the heat conduction coefficient increased with the increase in density value (Krüger and Adriazola, 2010). The reason for the increase in the heat conduction coefficient due to the increase in density of wood is shown to be less air-filled cell spaces (Suleiman et al., 1999). The greater the air gap in the wood, the lower the thermal conductivity of the wood material (Şahin Kol et al., 2008). When the fiber directions were examined, it was determined that the measurement made in parallel with the fibers gave higher thermal conductivity coefficient values than the measurement made vertically. The thermal conductivity of the wood material varies depending on the tree type, fiber directions in the same tree and the anatomical structure of the tree (Demir, 2014). Thermal conductivity value of wood material; It is also stated in the literature that it changes in direct proportion depending on the specific weight of the material, the amount of moisture, the amount of extractive material and the amount of temperature (Rice and Shepart, 2004; Aytaşkın, 2009; Sonderegger and Niemz, 2009; Demir, 2014).

When the effect of the type of insulation materials used in thermal conductivity measurements was examined, as can be seen from Figure 2, plywoods used with EPS gave the highest thermal conductivity values, while plywoods used with XPS gave the lowest values. It is known that the thermal conductivity coefficient of XPS plates used in the study is $0.033 \mathrm{~W} / \mathrm{mK}$, and that of EPS plates is $0.039 \mathrm{~W} / \mathrm{mK}$. As expected thermal conductivity values of the plywood samples decreased with the decreasing in thermal conductivity values of the insulation materials. It is a desired result that XPS plates, which are resistant to fire, transmit heat more difficultly and thus minimize the risk of fire. Uygunoğlu et al. (2015) determining the behavior of XPS and EPS types during fire, it was found that XPS boards are more resistant than other EPS types. In a study by Dikici and Kocagül (2019), thermal conductivity coefficients of EPS and XPS boards were compared and it was stated that the values of XPS boards were lower. It is recommended to use materials with low thermal conductivity coefficient values in studies where it is desired to improve the thermal insulation of buildings.

\section{CONCLUSION}

Today, it is a known fact that energy costs increase with the highest energy consumption in the building sector. For our country aiming to join the European Union, offering different solutions to energy efficiency is one of the most important issues. When the structures are examined, it is seen that heat losses occur from all directions. In a four-storey building, approximately $60 \%$ of the average heat losses are from the walls, $25 \%$ from the roofs, and $15 \%$ from the floors. It is important to carry out studies on the diversity of insulation 
materials, which are the main issues of heat loss in building walls, and to determine the most suitable one.

In this study, determining the type of materials that will add insulation feature to the wall and some factors belonging to the plywood used in coating the curtain walls were among the main goals. Accordingly, in the thermal conductivity coefficient measurements made within the scope of the study, it was seen that XPS boards could be more successful in the insulation properties of plywood. Although EPS boards are preferred over XPS boards due to their cheaper price, it is thought that this difference in fees can be ignored when energy costs are considered.

\section{ACKNOWLEDGMENTS}

This study was presented in ORENKO 2020 held by Karadeniz Technical University, Trabzon.

\section{REFERENCES}

ASTM C, 518. (2004). Methots of measuring thermal conductivity, absolute and reference method. ASTM International: West Conshohocken, USA.

Cetiner, I. \& Shea, A.D. (2018). Wood Waste as an Alternative Thermal Insulation For Buildings. Energy \& Buildings, 168, 374-384.

Demir, A. 2014. The effects of fire retardant chemicals on thermal conductivity of plywood produced from different wood species. Master Thesis, KTU Graduate School of Natural and Applied Sciences, Trabzon, Turkey.

Demirkır, C., Colak, S. \& Aydin, I. (2013). Some Technological Properties of Wood-Styrofoam Composite Panels, Composites: Part B, 55, 513-517.

Demirkır, M.S. (2014). The effects of pressing time and adhesive types on technological properties of plywood obtained from different wood species. Master Thesis, KTU Graduate School of Natural and Applied Sciences, Trabzon, Turkey.

Dikici, A. \& Kocagül, M. (2019). Experimental Comparison Of Eps, Xps And Stone Wool Insulation Material Used In Heat Insulation, Firat University Journal of Engineering, 31, 1.

Dissanayake, D.M.K.W., Jayasinghe, C. \& Jayasinghe, M.T.R. (2017). Comparative Embodied Energy Analysis of a House with Recycledexpanded Polystyrene (EPS) Based Foam Concrete Wall Panels. Energy and Buildings, 135, 85-94.

Fernando, P.L.N., Jayasinghe, M.T.R. \& Jayasinghe, C. (2017). Structural Feasibility of Expanded Polystyrene (EPS) Based Lightweight Concrete Sandwich Wall Panels. Construction and Building Materials, 139, 45-51.
Gu H. M. \& Zink-Sharp, A. (2005). Geometric model for softwood transverse thermal conductivity, Part I. Wood and Fiber Science, 37(4), 699-711.

Jang, M., Shim, W.J., Han, G.M., Song, Y.K. \& Hong, S.H. (2018). Formation of Microplastics by Polychaetes (Marphysa Sanguinea) Inhabiting Expanded Polystyrene Marine Debris. Marine Pollution Bulletin, 131, 365-369.

Kol, H. S., Özçifçi, A. \& Altun, S. (2008). Effect of Some Chemicals on Thermal Conductivity of Laminated Veneer Lumbers Manufactured with Urea formaldehyde and Phenol formaldehyde Adhesives. Kastamonu Univ. Journal of Forestry Faculty, 8(2), 125-130.

Krüger, E.L. \& Adriazola, M. (2010). Thermal Analysis of Wood-based test cells. Construction and Building Materials, 24(6), 999-1007.

Lakatos, A. \& Kalmar, F. (2013). Investigation of Thickness and Density Dependence of Thermal Conductivity of Expanded Polystyrene Insulation Materials. Materials and Structures, 46, 1101-1105.

Özdemir, F., Tutuş, A. \& Bal, B.C. (2013). Effect of fire retardants on thermal conductivity and limited oxygen index of high density fibreboard. SDU Faculty of Forestry Journal, 14, 121-126.

Rice, R.W. \& Shepard, R. (2004). The Thermal Conductivity of Plantation Grown White Pine (Pinus strobus) and Red Pine (Pinus resinosa) at two moisture content levels. Forest Products Journal, 54(1), 92-94.

Schmidta, P.N.S., Cioffia, M.O.H., Voorwalda, H.J.C. \& Silveira, J.L. (2011). Flexural Test on Recycled Polystyrene. Procedia Engineering, 10, 930-935.

Sekino, N. (2016). Density Dependence in The Thermal Conductivity of Cellulose Fiber Mats and Wood Shavings Mats: Investigation of The Apparent Thermal Conductivity of Coarse Pores. J. Wood Sci., 62, 20-26.

Sonderegger, W. \& Niemz, P. (2009). Thermal Conductivity and Water Vapour Transmission Properties of Wood Based Materials. Europen. Journal of Wood Products, 67, 313-321.

Suleiman, B.M., Larfeldt, J., Leckner, B. \& Gustavsson, M. (1999). Thermal Conductivity And Diffusivity of Wood. Wood Science and Technology, 33(6), 465-473.

Uygunoğlu, T., Güneş, İ., Çaliş, M. \& Özgüven, S. (2015). Investigation of Behavior of EPS and XPS Thermal Insulation Exterior Claddings During Fire. Journal of Polytechnic, 18(1), 21-28.

Uysal, B., Yapıcı, F., Kol H., Ş., Özcan, C., Esen, R. \& Korkmaz, M. (2011). Determination of thermal conductivity finished on impregnated wood material. 6th International Advanced Technologies Symposium (IATS'11). 